only preventable, but simple inexpensive interventions could lead to an increase in births of healthy infants with greater life expectancy.»

Marit P. Martinussen

Kvinneklinikken

St. Olavs hospital

\section{Hendig om hudsykdom hos barn}

Sue Lewis-Jones, red.

Paediatric dermatology

616 s, tab, ill. Oxford: Oxford University Press, 2010. Pris GBP 45

ISBN 978-0-19-920838-8

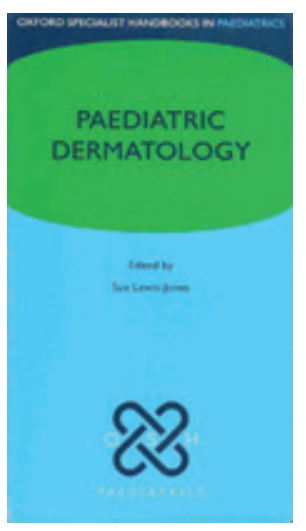

Pediatric Derma-

tology inngår

$i$ en serie med

medisinske hånd-

bøker, Oxford Spe-

cialist Handbooks.

I denne serien

foreligger nå en ny

bok, denne gangen

om hudsykdom-

mer hos barn og

ungdom.

Boken er dispo-

nert etter presentasjoner av hudfor-

andringene, og ikke i sykdomsgrupper. Fire av hovedseksjonene omhandler distribusjon av hudforandringene, type utslett (papu-

lære, pustuløse, urtikarielle etc.), overflateforandringer (blemmer, tumorer, ulcerasjoner etc.) og fargeendringer. I tillegg er det en innledende seksjon om generelle dermatologiske prinsipper og en seksjon om hudforandringer hos nyfødte.

Denne litt originale oppdelingen er bokens styrke. Hver enkelt tilstand blir omtalt i forskjellige kapitler, men indeksen og kryssreferansene fortløpende i teksten giør at det er forholdsvis lett å finne frem til stedet hvor den enkelte sykdommen er grundigst omtalt. Man skiller mellom vanlige og sjeldne tilstander, og det er oversiktlige algoritmer og lister med differensialdiagnoser. Formgivningen er tiltalende med fin veksling mellom fotografier, tabeller, tekst og faktabokser. Ved noen sykdommer gjør forfatterne dypdykk i genetiske eller molekylærbiologiske mekanismer, men den praktiske, kliniske tilnærmingen dominerer.

Sjeldne tilstander er kortfattet omtalt. Man bør konsultere andre kilder dersom det er behov for mer kunnskap, f.eks. tobindsverket av Bolognia og medarbeidere, som mange mener er dagens standardverk innen dermatologi (1). En alternativ håndbok er Color Atlas \& Synopsis of Pediatric Dermatology, som gjennomgående har høyere kvalitet på kliniske fotografier, et litt større format og med en mer tradisjonell disposisjon (2).

Boken har et hendig lommeformat og er trykket på tynt, matt papir med god kvalitet på bildene. Den har få mangler, og jeg kan anbefale den til leger som ønsker en håndbok om hudsykdommer hos barn og ungdom. Leseren bør ha noe forhåndskunnskap i dermatologi for lett å kunne anvende den. De mange tabellene og sjeldne diagnosene kan kanskje virke overveldende på en novise. Erfarne leger vil kunne ha god nytte av den, også som en rask oppfriskning.

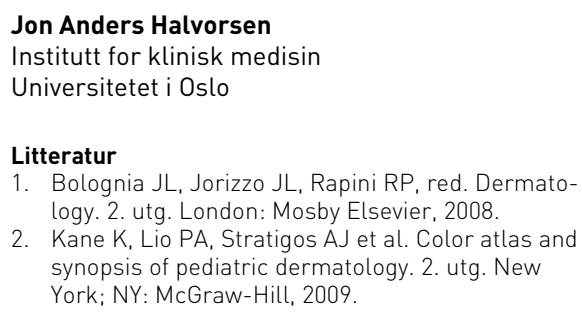

\section{Tankevekkende} om biobanker

Kris Dierichx, Pascal Borry, red.

New challenges for biobanks: ethics,

law and governance

277 s, ill. Mortsel: Intersentia Publishing, 2009. Pris EUR 62

ISBN 978-90-5095-974-2

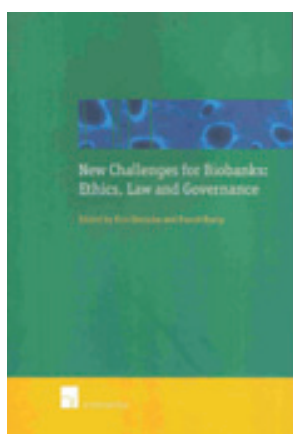

Biobanker er systematiske samlinger av humant biologisk materiale som blod og vev, innsamlet i forbindelse med diagnostikk, behandling, forskning eller rettslige unders $\varnothing-$ kelser. Biobanker, både arkivmate-

rialet og nye samlinger, er av uvurderlig betydning for medisinsk behandling og forskning, ikke minst i lys av utviklingen innen genomikk og informasjonsteknologi. Bruk av biologisk materiale medfører også en rekke etiske og rettslige dilemmaer som denne boken tar opp. Målgruppen angis å være sentrale politikere, lovgivere og fagfolk med ansvar for biobanker.

Dette er en samling artikler presentert på en internasjonal konferanse $\mathrm{i}$ Leuven i Belgia i 2009. Boken er inndelt i 19 kapitler med forskjellige forfattere, og forfatterne belyser en rekke temaer innen biobankvirksomhet, som informert samtykke, personvern, medbestemmelsesrett, kommersialisering, rettsmedisin, forskjeller innen europeisk lovregulering og kulturelle perspektiver. Kapitlet om kommersialise- ring er skrevet av forfattere fra Norges teknisk-naturvitenskapelige universitet. Hvert kapittel avsluttes med utfyllende referanser og fotnoter. Bakerst er det en liste over bidragsyterne med et kort sammendrag av nåværende funksjoner og interessefelt.

Biobanker er i Norge lovregulert hovedsakelig gjennom behandlingsbiobankloven, som regulerer diagnostikk- og behandlingsbiobanker, og helseforskningsloven, som regulerer forskningsbiobanker. Balansen mellom nødvendig ivaretakelse av personvern og unødvendig byråkratisering og lovregulering innen medisinsk forskning er et tema som stadig debatteres. Forfatterne gir en rekke viktige bidrag til denne diskusjonen. Hvordan skal f.eks. forskeren ivareta informasjonsplikten overfor donoren av biobankmaterialet? Hva er tilstrekkelig informasjon? Hvor bredt kan et samtykke være? Aktualiteten illustreres ved at Helseog omsorgsdepartementet i mars 2010 utga en omfattende veileder som vedlegg til helseforskningsloven, hvor man spesielt kommenterer informasjonsplikten og samtykke.

I kapitlet om kommersialisering av biobanker er erfaringer fra HUNT Biosciences AS i Nord-Trøndelag sammenliknet med UK Biobank og deCODE genetics. Dette er høyst relevant, ikke minst i lys av at Forskningsrådet gjennom to rapporter, Gode biobanker - bedre helse (1) og Potensial for kommersiell utnyttelse av humane biobanker (2), slår fast at kommersialisering er nødvendig for å optimalisere helsegevinster basert på forskning med biobankmateriale.

Rettsmedisinske biobanker er omtalt i flere kapitler. De fleste EU-land og USA har rettsmedisinske DNA-banker som inneholder DNA fra åstedsundersøkelser og DNA fra dømte, enkelte også DNA-prøver fra mistenkte. Dette har konsekvenser for individers rettsvern og personvern, og forholdet mellom frihet på den ene siden og sikkerhet på den andre siden problematiseres. Forfatterne klargjør forskjellen mellom det å oppbevare kun DNA-profiler, som bygger på ikke-kodende områder, og DNA-prøver som inneholder hele genomet.

Avslutningsvis er det en beskrivelse av drivkreftene bak store EU-baserte biobankprosjekter som BBMRI (Biobanking and Biomolecular Resources Research Infrastructure). Det vitenskaplige forskningsfokuset på systembiologien, hvor årsaksforståelsen av sykdom krever store multinasjonale biobanker, fordrer at vi lykkes med en europeisk harmonisering og standardisering av de humane biobankene på tvers av landegrensene.

Jeg anbefaler boken for lovgivere og andre med interesse og forvaltningsansvar for biobanker.

\section{Wenche Reed}

Stab forskning og utvikling

Oslo universitetssykehus, Ullevål 